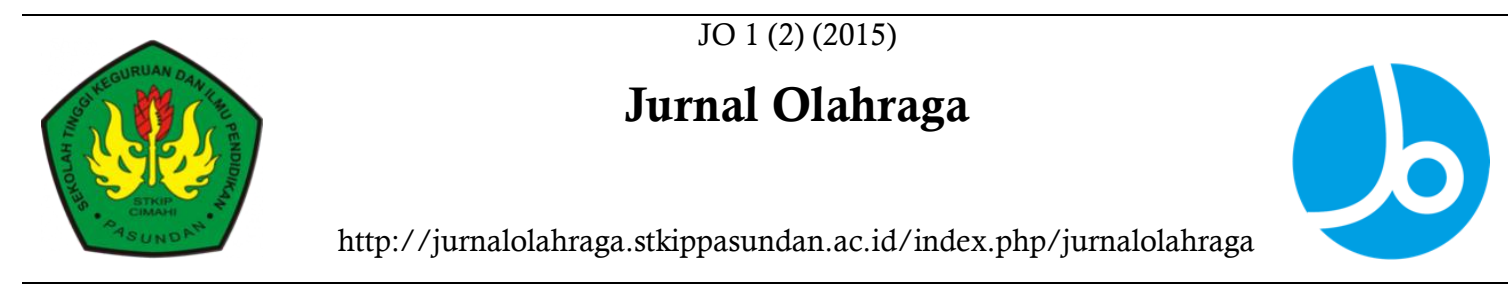

\title{
Hubungan Koordinasi Mata-Tangan, Power Tungkai Dan Percaya Diri Terhadap Hasil Keterampilan Lay-Up Shoot
}

\begin{tabular}{l} 
Info Artikel \\
\hline Sejarah Artikel: \\
Diterima Agustus 2015 \\
Disetujui Oktober 2015 \\
Dipublikasikan Oktober 2015 \\
\hline Keywords: \\
Lay up, Kordinasi Mata \\
Tangan, Power Tungkai, \\
Percaya Diri. \\
\hline
\end{tabular}

Yopi Meirijal

STKIP Pasundan, Indonesia

\begin{abstract}
Abstrak
Tujuan yang ingin dicapai dalam penelitian ini adalah untuk mengetahui : (1) Hubungan langsung koordinasi mata-tangan terhadap hasil keterampilan lay up shoot pada permainan bola basket. (2) Hubungan langsung power tungkai terhadap hasil keterampilan lay up shoot pada permainan bola basket. (3) Hubungan langsung percaya diri terhadap hasil keterampilan lay up shoot pada permainan bola basket.(4) Hubungan secara bersama sama antara Koordinasi Mata-Tangan, power dan percaya diri terhadap keterampilan lay up shoot pada permainan bola basket. Metode penelitian yang digunakan untuk mencapai hasil penelitian yakni menggunakan deskripif dengan study korelaional. Populasi diambil dari mahsiswa angkatan 2012 - 2013 di kampus STKIP Pasundan Cimahi, populasi yang diambil sebanyak 133 orang sedangkan dijadikan sampel sebanyak 80 orang. Berdasarkan hasil penelitian dan hasil analisis data yang telah dilakukan dapat di peroleh data sebagai berikut : (1) Terdapat hubungan yang signifikan antara koordinasi mata dengan keterampilan lay up shoot dalam cabang olahraga bola basket. (2) Terdapat hubungan yang signifikan antara power tungkai dengan keterampilan lay up shoot dalam cabang olahraga bola basket. (3) Terdapat hubungan yang signifikan antara percaya diri dengan keterampilan lay up shoot dalam cabang olahraga bola basket. (4) Terdapat hubungan secara bersama-sama yang signifikan antara koordinasi mata-tangan, power tungkai dan percaya diri terhadap hasil keterampilan lay-up shoot dalam cabang olahraga bola basket
\end{abstract}

\begin{abstract}
The objectives to be achieved in this study are to find out: (1) The direct relationship of eye-hand coordination to the results of lay-up shoot skills in basketball games. (2) The direct relationship of leg power to the results of lay-up shoot skills in basketball games. (3) Direct relationship of confidence in the results of lay-up shoot skills in basketball games (4) A joint relationship between Eye-Hand Coordination, power and confidence in lay-up shooting skills in basketball games. The research method used to achieve research
\end{abstract}


results using descriptive with correlational studies. The population was taken from the 2012-2013 class of students at the Pasundan Cimahi STKIP campus, the population taken was 133 people while the sample was 80 people. Based on the results of research and the results of data analysis that has been carried out, the following data can be obtained: (1) There is a significant relationship between eye coordination with lay-up shoot skills in basketball. (2) There is a significant relationship between leg power and lay-up shoot skills in basketball. (3) There is a significant relationship between selfconfidence and lay-up shoot skills in basketball. (4) There is a significant joint relationship between eye-hand coordination, leg power and confidence in the results of shoot lay-up skills in basketball

(C) 2015 Yopi Meirijal Under the license CC BY-SA 4.0

$凶$ Alamat korespondensi: ISSN 2442-9661 (cetak)

E-mail:

\section{PENDAHULUAN}

Dewasa ini olahraga bola basket berkembang dengan pesat, hal ini dapat dibuktikan dengan makin banyak berdirinya klub atau kegiatan di lingkungan sekolah dan juga banyak diselenggarakannya kejuaraan bola basket yang bersifat daerah, nasional dan internasional. Jenis olahraga ini melibatkan banyak orang, kebanyakan dimainkan oleh anak muda dengan pemain terbanyak pria remaja, permainan bola basket juga dapat dimainkan oleh pria maupun wanita dari segala usia dan ukuran tubuh bahkan oleh mereka yang kekurangan dalam hal fisik. Bola basket ditemukan sebagai olahraga dalam ruangan (indoor sport) dan sekarang dimainkan baik di dalam maupun luar ruangan.

Bola basket adalah olahraga yang dimainkan oleh dua regu, dan saling memasukkan bola ke keranjang lawan dengan tangan. Permainan ini diciptakan oleh Prof. James Naismith seorang instruktur pendidikan jasmani pada YMCA (Young Mens Christian Association), Springfield, Massachusets, Amerika Serikat tahun 1891.

Permainan bola basket dapat menimbulkan rasa puas bagi orang yang melihatnya, apabila dalam permainan tersebut pemain mampu bermain dengan baik, melakukan teknik-teknik permainan dengan benar, disertai kerja sama antar pemain dalam satu tim yang baik, membuat tim akan lebih tangguh dan susah untuk dikalahkan. Oleh karena itu untuk bisa bermain bola basket harus menguasai teknik bermain bola basket dan untuk dapat melakukan permainan bola basket, seseorang harus menguasai teknikteknik dasar bermain bola basket dengan baik secara individu. Bola basket bukan permainan tim saja tetapi juga merupakan permainan yang membutuhkan keterampilan individual. Ada beberapa teknik dasar yang perlu dikuasai oleh pemain bolabasket seperti yang di tulis dalam buku ajar bola basket untuk mahasiswa yaitu: Stance (bentuk tubuh), Pivot (perputaran), Ballhandling (Penguasaan bola), Passing dan cathing (mengumpan dan menangkap), Shooting (menembak), Lay up shoot dan Driblling.

Lay up shoot menurut Sukintaka dalam Rismayadi (2009) bahwa: 'Lay up shoot ialah tembakan yang dilakukan dengan jarak dekat sekali dengan keranjang, hingga seolah-olah bola itu diletakan ke dalam keranjang yang dilakukan dengan gerakan melangkah lebar dan melompat setinggi-tingginya. Berdasarkan uraian tersebut, latihan lay up 
shoot memerlukan kemampuan mengkoordinasikan beberapa teknik lay up shoot menjadi satu kesatuan yang utuh. Hal tersebut sesuai dengan batasan koordinasi yang dikemukakan oleh Harsono (1988) yaitu, 'Koordinasi adalah kemampuan biomotorik untuk. memadukan berbagai macam gerakan ke dalam satu atau lebih pola gerakan khusus'.

Koordinasi juga pening apabila kita mendapakan situasi yang baru misalkan lapangan yang baru, peralatan, cuaca, lampu penerangan ataupun lawan yang memang diluar dari apa yang kita predksikan. Broer dan Zernicke dalam Harsono menerangkan bahwa koordinasi adalah kemampuan untuk mengkoordinasikan beberapa gerakan tanpa ketegangan, dengan urutan yang benar, dan melakukan gerakan yang kompleks secara mulus tanoa mengluarkan enersi yang berlebihan.

Percaya diri adalah pikiran positif, perasaan dan tindakan yang mencerminkan keyakinan bahwa kita dapat berhasil mencapai tujuan. Ketika seseorang raguragu/tidak yakin pada diri sendiri, maka kemungkinan seseorang untuk meraih sukses sangatlah kecil. Jadi, bisa disimpulkan, ketika siswa tidak yakin akan kemampuannya sendiri, maka sulit bagi siswa untuk selalu konsisten. Rasa percaya diri akan mendongkrak semangat belajar siswa. Percaya diri merupakan suatu keyakinan dan sikap seseorang terhadap kemampuan pada dirinya sendiri dengan menerima secara apa adanya baik fositif maupun negative yang dibentuk dan dipelajari melalui proses belajar dengan tujuan untuk kebahagiaan dirinya. Adapun tujuan dalam penelitian ini untuk mengetahui apakah koordinasi mata-tangan, power tungkai dan percaya diri terhadap hasil keterampilan lay-up shoot .

\section{METODE}

Metode penelitian adalah suatu cara yang ditempuh untuk memperoleh data, menganalisis dan menyimpulkan hasil penelitian. Penggunaan metode dalam pelaksanaan penelitian adalah hal yang sangat penting, oleh sebab itu dalam menggunakan metode penelitian yang tepat diharapkan dapat mencapai tujuan yang diinginkan. Disamping itu penggunaan metode tergantung kepada permasalahan yang akan dibahas, dengan kata lain penggunaan suatu metode dilihat dari efektivitasnya, efesiensinya dan relevansinya metode tersebut.

Metode penelitian yang di gunakan dalam penelitian ini adalah metode diskriptif dengan studi korelasional, dengan menggunakan analisis regresi ganda yang bertujuan untuk mengetahui ada tidaknya hubungan koordinasi mata-tangan, power, dan percaya diri terhadap keterampilan lay up shoot. Serta menjelaskan hubungan setiap variabel bebas dengan variabel terikat baik secara tersendiri-sendiri maupun bersamasama.

\section{HASIL DAN PEMBAHASAN}

Dikemukakan dengan bahasa yang jelas, padat merupakan hasil analisis data untuk menjawab pertanyaan penelitian termasuk teori, fakta, opini berdasarkan literature penelitian terdahulu yang mendukung. Dapat disertai ilustrasi (gambar atau grafiik). Proporsi bagian ini adalah 40$60 \%$. Hasil data penelitian yang diperoleh dari lapangan, akan digambarkan nilai-nilai data dengan menggunakan ukuran rata-rata, nilai tertinggi, nilai terendahnya, untuk dapat memberikan informasi mengenai data Koordinasi Mata-Tangan, Power tungkai, Percaya diri, Keterampilan lay up shoot dan kecepatan pukulan sampel penelitian. Hasil 
deskriptif untuk variabel penelitian dapat dilihat pada tabel berikut :

\begin{tabular}{|c|c|c|c|c|c|}
\hline & $\begin{array}{c}\text { M } \\
\text { in }\end{array}$ & Maks & $\begin{array}{c}\text { Jum } \\
\text { lah }\end{array}$ & $\begin{array}{c}\text { Rata } \\
\text {-rata }\end{array}$ & $\begin{array}{c}\text { Std. } \\
\text { Deviasi }\end{array}$ \\
\hline $\begin{array}{c}\text { Koordinasi Mata- } \\
\text { Tangan (X1) }\end{array}$ & 10 & 18 & $\begin{array}{c}114 \\
7\end{array}$ & $\begin{array}{c}14.3 \\
375\end{array}$ & $\begin{array}{c}1.8276 \\
6\end{array}$ \\
\hline $\begin{array}{c}\text { Power tungkai } \\
\text { (X2) }\end{array}$ & $\begin{array}{c}25 \\
0\end{array}$ & 290 & $\begin{array}{c}215 \\
60\end{array}$ & $\begin{array}{c}269 . \\
5000\end{array}$ & $\begin{array}{c}8.2906 \\
1\end{array}$ \\
\hline Percaya diri (X3) & 13 & 220 & $\begin{array}{c}144 \\
83\end{array}$ & $\begin{array}{c}181 . \\
0375\end{array}$ & $\begin{array}{c}16.958 \\
96\end{array}$ \\
\hline $\begin{array}{c}\text { Keterampilan lay } \\
\text { up shoot (Y) }\end{array}$ & 1 & 7 & 335 & $\begin{array}{c}4.18 \\
75\end{array}$ & $\begin{array}{c}1.6076 \\
9\end{array}$ \\
\hline
\end{tabular}

Tabel 1. Deskripsi Data Penelitian

Korelasi antar variabel menunjukkan hubungan secara signifikan antara variabel. Uji ini dilakukan dengan menggunakan program SPSS. Hasil analisis diperoleh koefisien korelasi sebagai berikut:

Tabel 2. Rekapitulasi Korelasi

\begin{tabular}{|c|c|c|}
\hline \multicolumn{3}{|c|}{ Correlations $^{\mathrm{a}}$} \\
\hline & & $\begin{array}{l}\text { Keterampilan } \\
\text { lay up shoot } \\
\text { (Y) }\end{array}$ \\
\hline \multirow{3}{*}{$\begin{array}{l}\text { Koordinasi Mata- } \\
\text { Tangan (X1) }\end{array}$} & & 530 \\
\hline & Correlation & \\
\hline & Sig. (2-tailed) & .000 \\
\hline \multirow{3}{*}{ Power tungkai (X2) } & Pearson & 502 \\
\hline & Correlation & .502 \\
\hline & Sig. (2-tailed) & .000 \\
\hline \multirow{3}{*}{ Percaya diri (X3) } & Pearson & 566 \\
\hline & Correlation & \\
\hline & Sig. (2-tailed) & .000 \\
\hline
\end{tabular}

Hasil untuk korelasi antara variabel Koordinasi Mata-Tangan (X1) dengan Keterampilan lay up shoot (Y) adalah 0,530 dengan nilai signifikansi 0,000 . Nilai korelasi yang diperoleh menunjukkkan bahwa hubungan Koordinasi Mata-Tangan (X1) dengan Keterampilan lay up shoot (Y) masuk kategori cukup kuat (berada pada interval 0,4 -0,6). Hasil korelasi antara variabel Power tungkai (X2) dengan Keterampilan lay up shoot (Y) adalah 0,528 dengan nilai signifikansi 0,000 . Nilai korelasi yang diperoleh menunjukkkan bahwa hubungan Power tungkai (X2) dengan Keterampilan lay up shoot (Y) masuk kategori cukup kuat (berada pada interval 0,4 -0,6). Hasil korelasi antara variabel Percaya diri (X3) dengan Keterampilan lay up shoot (Y) adalah 0,566 dengan nilai signifikansi 0,0002. Nilai korelasi yang diperoleh menunjukkkan bahwa hubungan Percaya diri (X3) dengan Keterampilan lay up shoot (Y) masuk kategori cukup kuat (berada pada interval 0,4 $-0,6)$.

Untuk menguji signifikansi hubungan masing-masing dengan Keterampilan lay up shoot (Y) digunakan uji t. Untuk $\mathrm{n}=80$ diperoleh nilai t tabel dengan $\mathrm{db}=78$ adalah 1,991. Nilai t hitung untuk korelasi antara variabel Koordinasi Mata-Tangan (X1) dengan Keterampilan lay up shoot (Y) dari hasil perhitungan diperoleh sebesar 5,514. Karena $|\mathrm{t}|$ hitung $(=5,514)>\mathrm{t}$ tabel $(=1,991)$ maka $\mathrm{H}_{0}$ ditolak atau nilai sig $(0,000)<0,05$, maka $\mathrm{H}_{0}$ ditolak. Artinya hubungan antara Koordinasi Mata-Tangan (X1)dengan Keterampilan lay up shoot (Y) bermakna (signifikan). 
Nilai t hitung untuk korelasi antara variabel Power tungkai (X2) dengan Keterampilan lay up shoot (Y) dari hasil perhitungan diperoleh sebesar 6,316. Karena $|\mathrm{t}|$ hitung $(=6,316)>\mathrm{t}$ tabel $(=1,991)$ maka $\mathrm{H}$ ${ }_{0}$ ditolak atau nilai sig $(0,000)<0,05$, maka $\mathrm{H}_{0}$ ditolak. Artinya hubungan antara Power tungkai (X2) dengan Keterampilan lay up shoot (Y) bermakna (signifikan).

Nilai $\mathrm{t}$ hitung untuk korelasi antara variabel Percaya diri (X3)dengan Keterampilan lay up shoot (Y) dari hasil perhitungan diperoleh sebesar 5,514. Karena $|t|$ hitung $(=6,059)>t$ tabel $(=1,991)$ maka $\mathrm{H}$ ${ }_{0}$ ditolak atau nilai sig $(0,000)<0,05$, maka $\mathrm{H}_{0}$ ditolak. Artinya hubungan antara Percaya diri (X3)dengan Keterampilan lay up shoot (Y) bermakna (signifikan)

1. Persamaan Regresi Ganda Keterampilan lay up shoot (Y) atas Koordinasi MataTangan (X1), Power tungkai (X2),Percaya diri (X3)

Hasil koefisien regresi untuk Koordinasi Mata-Tangan (X1), Power tungkai (X2),Percaya diri (X3) terhadap Keterampilan lay up shoot $(\mathrm{Y})$ dapat dilihat pada Tabel 4.28.Nilai konstanta (a) dan koefisen regresi (b) dari perhitungan SPSS 20 yang diperoleh sebagai berikut :

Tabel 3. Hasil Koefisien Regresi X1, X2,

\section{X3 terhadap Y}

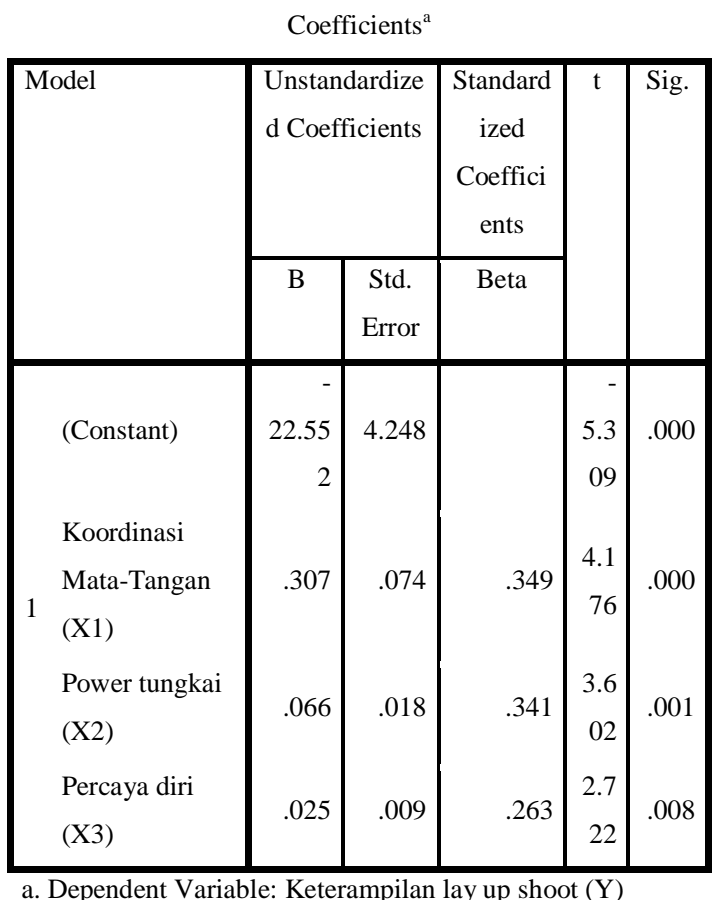

Berdasarkan hasil perhitungan di atas diperoleh persamaan regresi linier sebagai berikut :

$\hat{\mathrm{Y}}=-22.552+0,307 \mathrm{X} 1+0,066 \mathrm{X} 2+$ $0,025 \mathrm{X} 3$

Diperoleh nilai konstanta (a) sebesar 22.552Ini berarti pada saat Koordinasi MataTangan (X1), Power tungkai (X2),Percaya diri (X3)tidak berubah atau tetap (0)besarnya rata-rata Keterampilan lay up shoot $(\mathrm{Y})=$ 4,452 .

Pada saat Power tungkai (X2) dan Percaya diri (X3)tidak ada perubahankoefisien regresi Koordinasi Mata$\begin{array}{llll}\text { Tangan } & \mathrm{X} 1 \quad \text { sebesar } & 0,307\end{array}$ menunjukanKoordinasi Mata-Tangan (X1)memberikan sumbangan terhadap peningkatan Keterampilan lay up shoot (Y) sebesar 0,307. Artinya semakin baik 
Koordinasi Mata-Tangan akan meningkatkan

Keterampilan lay up shoot.

Pada saat Koordinasi Mata-Tangan (X1)dan Percaya diri (X3) tidak ada perubahanKoefisien regresi Power tungkai (X2)sebesar 0,066 menunjukkan Power tungkai (X2) memberikan sumbangan terhadap peningkatan Keterampilan lay up shoot $(\mathrm{Y})$ sebesar 0,066. Artinya semakin baik Power tungkai akan meningkatkan Keterampilan lay up shoot.

Pada saat Koordinasi Mata-Tangan (X1)dan Power tungkai (X2) tidak ada perubahankoefisien regresi Percaya diri (X3)sebesar 0,025 menunjukkan Percaya diri (X3)memberikan sumbangan terhadap peningkatan Keterampilan lay up shoot (Y) sebesar 0,025. Artinya semakin baik Percaya diri akan meningkatkan Keterampilan lay up shoot.

\section{Pengujian Keberartian Koefisien Regresi}

Berganda Keterampilan lay up shoot (Y) atas Koordinasi Mata-Tangan (X1), Power tungkai (X2),Percaya diri (X3)

Hasil analisis yang diperoleh untuk koefisien korelasi Ganda Koordinasi MataTangan (X1), Power tungkai (X2),Percaya diri (X3) secara bersama-sama dengan Keterampilan lay up shoot (Y) adalah sebesar 0,729 .

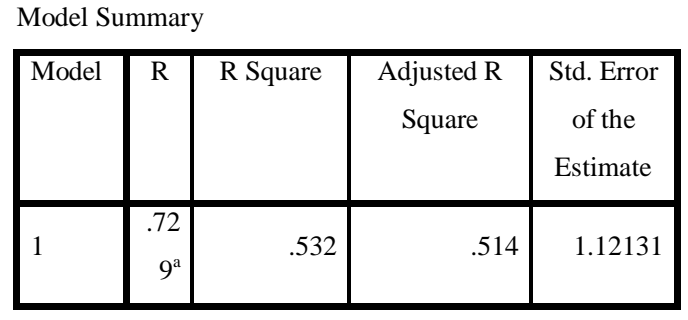

Tabel 4. Korelasi Ganda

Koordinasi Mata-Tangan (X1), Power tungkai (X2). Nilai korelasi yang diperoleh menunjukkkan bahwa hubungan Koordinasi Mata-Tangan (X1), Power tungkai (X2),Percaya diri (X3)dengan Keterampilan lay up shoot (Y) masuk kategori kuat (berada pada interval 0,6 -0,8). Untuk menguji signifikansi hubungan Koordinasi MataTangan (X1), Power tungkai (X2),Percaya diri (X3) dengan Keterampilan lay up shoot (Y) digunakan uji F. Nilai F hitung dari hasil perhitungan diperoleh sebesar 28,799. Untuk $\mathrm{n}=80$ diperoleh nilai $\mathrm{F}$ tabel dengan $\mathrm{db} 1=3$ dan $\mathrm{db} 2=76$ adalah 2,725 . Karena F hitung $(=28,7992) \quad>\mathrm{F}$ tabel $(=2,725)$ maka $\mathrm{H}_{0}$ ditolak atau nilai sig $(0,000)<0,05$, maka $\mathrm{H}_{0}$ ditolak. Artinya sumbangan atau kontribusi Koordinasi Mata-Tangan,Power tungkai,dan Percaya diri secara bersama-sama terhadap Keterampilan lay up shoot bermakna (signifikan).

1. Terdapat hubungan antara Koordinasi Mata-Tangan dengan keterampilan lay up shoot

Gerakan lay up shoot dalam permainan bola basket merupakan salah satu gerakan melangkah yang dilanjutkan dengan menolak 
yang kemudian di ikuti dengan gerakan melayang di udara sambil mendorongkan lengan kea rah ring. Koordinasi gerak dalam permainan bola basket merupakan gabungan kemampuan mengiring bola, melangkah serta melompat setinggi-tingginya dengan menjaga keseimbangan pada saaat melayang di udara.

Indikator koordinasi dari mata-tangan yaitu kecepatan dan ketepatan sstem energy, kontraksi otot syaraf dan tulang. Dengan memiliki koordinasi yang baik antara matatanggan maka pada saat melangkahpun langkahan kanan di ikuti dengan yang kiri sambil menolak hingga akhirnya mengarahkan lengan dengan mengangkat tungkai kanan seirama dengan ayunan tangan kea rah ring basket.

Dengan demikian diduga terdapat hubungan antara mata-tangan terhadap keterampilan lay up shoot pada permainan bola basket. Pada permainan bola basket teknik lay up sangatlah penting, dimana lay up merupakan satu cara memasukan bola yang lebih mudah dan tingkat persentase masuknya lebih tinggi.

2. Terdapat hubungannya antara power dengan keterampilan lay up shoot

Menurut Kosasih "lompatan yang tinggi dibuat dengan jejakan kaki terakhir sebelum melompat, jadi usahakan lompatan kita mendekati ring..Lay up shot dapat dilakukan dengan 2 (dua) hitungan kaki ataupun dengan 1 (satu) hitungan kaki." Danny :2008 mengungkapkan Untuk melompat tinggi dalam lay up pemain harus mempunyai tolakan yang kuat (power menolak) karena tinggi rendahnya lompatan tergantung dari kuat atau tidaknya tolakan tersebut. Koordinasi langkah dari langkah pertama kemudian langkah ke dua yang dibarengi dengan tolakan yang kuat hingga akhirnya bisa melayang dengan mengarahkan lengan ke akea ring.

3. Terdapat hubungannya antara percaya diri dengan keterampilan lay up shoot

Kepercayaan diri merupakan faktor penentu dalam penampilan, karena menjadi faktor penentu makakepercayaan diri harus bersifat optimal. Kepercayaan diri yang berlebihan terjadi apabila kepercayaan pribadi bisa melebihi kepercayaan diri kawan.

Lay up shoot terkadang menjadi teknik yang sulit bagi mahasiswa dalam proses pembelajaran, semua ini dikarenakan salah satunya adalah kurangnya rasa percaya diri yang kurang pada saat akan melakukan lay up shoot. Koordinasi langkah, lengan, serta tolakan dan layangan untuk memasukan bola ke ring basket terkadangmenjadi salah satu yang menyebabkan lay up itu dianggap sulit. Dari sulitnya itu pengaruh percaya dirilah salah satunya yang harus di latih.

\section{KESIMPULAN}

Sesuai dengan permasalahan yang ada dan data yang telah dikumpulkan, serta hasil analisis yang telah dilakukan, akhirnya peneliti mengambil kesimpulan sebagai berikut :

1. Terdapat hubungan yang signifikan antara koordinasi mata dengan keterampilan lay 
up shoot dalam cabang olahraga bola basket.

2. Terdapat hubungan yang signifikan antara power tungkai dengan keterampilan lay up shoot dalam cabang olahraga bola basket

3. Terdapat hubungan yang signifikan antara percaya diri dengan keterampilan lay up shoot dalam cabang olahraga bola basket

4. Terdapat hubungan secara bersama-sama yang signifikan antara koordinasi matatangan, power tungkai dan percaya diri terhadap hasil keterampilan lay-up shoot dalam cabang olahraga bola basket.

Sesuai dengan hasil penemuan penelitian, maka terdapat beberapa rekomendasi, sebagai berikut:

1. Sebagai peningkatan keterampilan lay-up shoot pada permainan bola basket, sehingga diharapkan pelatih ataupun Pembina bisa mengetahui koordinasi mata tangan, power tungkai serta percaya diri.

2. Dalam menyusun program latihan untuk meningkatkan prestasi kemampuan lay up shoot pada permainan bola basket, hendaknya pelatih ataupun Pembina mengetahui serta memperhitungkan unsur dari koordinasi mata tangan, power tungkai, percaya diri.

3. Untuk mencapai prestasi kemampuan lay up shoot pada permainan bola basket tidak hanya unsur koordinasi mata tangan, power tungkai serta percayadiri saja, masih banyak penunjang lain yang mesti dikaji serta di teliti lebih mendalam lagi.

\section{DAFTAR PUSTAKA}

Rismayadi, Alen, (2009), Buku Ajar Bola Basket. Bandung : STKIP Pasundan Cimahi.

Rismayadi, Alen, (2009) Efektivitas Model Latihan Menggunakan Rintangan dan Tidak Menggunakan Rintangan Terhadap Hasil Latihan Keterampilan Lay Up shoot Dalam Permainan Bolabasket Siswa SMP Negeri 7 Bandung. FPOK. Universitas Pendidikan Indonesia.

Harsono, (1988), Coaching Dan AspekaspekPsikologisDalam Coaching. Jakarta: C.V. TambakKusuma. 